\title{
Factors Affecting Abundance and Damage Caused by Cabbage Aphid, Brevicoryne brassicae on Four Brassica Leafy Vegetables: Brassica oleracea var. Acephala, B. chinense, B. napus and B. carinata
}

\author{
D.C. Munthali ${ }^{*}$ and A.B. Tshegofatso
}

Botswana College of Agriculture, P/Bag 0027, Gaborone, Botswana

\begin{abstract}
Resistance of four brassica leafy vegetables: kale, Chinese cabbage, rape and Ethiopian mustard to cabbage aphid, Brevicoryne brassicae (L.) was studied in cage experiments at the Botswana College of Agriculture, Gaborone, Botswana. A completely randomised design with cultivars as treatments and four replicates per treatment was used. One newly laid nymph was placed on each of the four potted plants of each cultivar and left to breed. Aphid abundance and damage on each cultivar were recorded weekly for six weeks. Direct counts of aphids were made to estimate abundance while the proportions of leaves with honeydew were used to measure intensity of damage. Chlorophyll, water and protein content and leaf thickness were estimated and their effects on aphid abundance and damage intensity were determined. Aphid populations on all cultivars peaked in the third week. Peak populations differed significantly $(\mathrm{P}<0.05)$ between cultivars, with the greatest (828.2 per leaf) on Chinese cabbage and the least (307 per leaf) on Ethiopian mustard. Cabbage aphids caused significantly $(\mathrm{P}<0.05)$ greater reduction of marketable leaves on kale than on the other cultivars. Cultivars with high chlorophyll; high water content and the thickest leaves had lower abundance of cabbage aphid than those with significantly $(\mathrm{P}<0.05)$ lower chlorophyll and water content and thinner leaves; those with thicker leaves, high protein and high water content suffered greatest honeydew damage. Therefore breeding for low protein and water content, high chlorophyll content and thin leaves is recommended because the cultivar produced would suffer low honeydew damage.
\end{abstract}

Keywords: Brassica leafy vegetables, cabbage aphid, damage.

\section{INTRODUCTION}

Brassica leafy vegetables: Brassica oleracea var. Acephala (kale), B. chinense (Chinese cabbage), B. napus (rape) and $B$. carinata (Ethiopian mustard) belong to the family Brassicaceae. They are widely cultivated in Africa and utilized primarily as greens in cooked dishes and as salads [1]. They are grown for domestic use as well as for market. Brassica leafy vegetables have high mineral and vitamin content. Chinese cabbage, kale and rape have been cultivated in Botswana for many years [2] while Ethiopian mustard has only recently been recommended for cultivation in the country [3]. Insect pest species that commonly infest brassica leafy vegetables include: Plutella xylostella (L.) (diamond back moth), Agrotis spp. (cutworm), Bagrada hilaris (Burn) (Bagrada bug) and Brevicoryne brassicae (L.) (cabbage aphid). The cabbage aphid (B. brassicae L.) is an important pest of brassicas [4-7]. It can cause total crop loss on brassica leafy vegetables [8]. Its pest status is enhanced by its high reproductive capacity. One mature aphid can give birth to 2 to 5 live young per day which mature in 5 to 7 days after birth [9]. A mature cabbage aphid can produce offspring for up to 30 days. The species breeds throughout the year. As many as 20 generations can be completed in a year.

*Address correspondence to this author at the Botswana College of Agriculture, P/Bag 0027, Gaborone, Botswana;

Tel: +2673187452 or +2673650216 ; Fax: +2673928753 ;

E-mails:dc.munthali@yahoo.com ordmunthali@bca.bw
Cabbage aphids occur in large numbers on leaves and growing points of infested leafy vegetables. They tend to feed on the undersides and damage plants by piercing and sucking sap from attacked parts, causing yellowing and curling of the leaves.

In Botswana $[2,7]$ cabbage aphid populations tend to build up quickly on infested plants because the species has high reproductive capacity, especially during warm weather. This results in stunted growth and deformation of the plant [10]. Infestation reduces the quality of the production through their presence and by contamination of the leaves with exuvae, wax, honeydew and sooty mould that grows on the honeydew [10]. Cabbage aphids also transmit Tulip Mosaic Virus to cabbage [11]. It is necessary for farmers to control the pest to prevent serious yield losses. When farmers notice large pest infestations on their crops, they often look for effective insecticides to apply. Obopile et al. [12] found that over ninety eight percent of vegetable farmers in Botswana heavily rely on insecticides for the control of serious pests of brassicas. However, although a range of effective insecticides are available [13], many growers (especially subsistence farmers) cannot afford them. Apart from killing the pests, most effective insecticides are also lethal to nontarget beneficial insects. Furthermore, some of the insecticides are persistent and consequently require long waiting periods before treated produce can be consumed [13]. Frequent application of pesticides tends to induce resistance in the target insect pest population, making the pesticides inef- 
fective $[14,15]$. Therefore there is a need to identify effective, environmentally friendly and affordable alternative methods of controlling aphids.

Resistant cultivars of rape, Brussels sprouts and cabbage to the cabbage aphids have been reported from India, Europe and Botswana [16-21]. Some species and cultivars of brassicas have been more resistant to cabbage aphid infestations than others [18, 19, 22, 23]. However, Collier and Finch [24] found that the level of resistance to aphids was not sufficient to ensure that cultivars remained aphid-free. Van Emden [25] showed that partial host plant resistance can allow the use of a lower dose of insecticide to be effective when aphid populations exceed a threshold. In brassicas, the mechanisms that have been found to confer resistance against the cabbage aphid are antibiosis and antixenosis [18, 19, 21]. The potential use of brassica leafy vegetables to control cabbage pests has not yet been investigated in Botswana. Although several brassica leafy vegetables are recommended for use in Botswana $[2,3,7]$, their relative resistance to the cabbage aphid has not been determined. Therefore the objective of this study was to evaluate four commonly grown brassica leafy vegetables for resistance to the cabbage aphid and determine factors that influence abundance and damage caused.

\section{MATERIALS AND METHODS}

Four leafy vegetables: Brassica oleraceae var Acephala (kale), B. chinense (Chinese cabbage), B. napus (rape) and $B$. carinata (Ethiopian mustard) belonging to the family Brassicaceae were evaluated for resistance to the cabbage aphid B. brassicae; factors that affect abundance of the pest and the damage the pest causes on each cultivar. The study was conducted in cage experiments; under semi-field conditions; at minimum daily temperatures of $21.6 \pm 0.243^{\circ} \mathrm{C}$; maximum daily temperatures of $31.0 \pm 0.458^{\circ} \mathrm{C}$ and average rainfall of $1.14 \mathrm{~mm}$; at the Botswana College of Agriculture, Gaborone Botswana (Longitude $25^{\circ} 54^{\prime}$ E, Latitude $24^{\circ} 33^{\prime}$ $\mathrm{S}$, altitude $994 \mathrm{~m}$ ). A completely randomised design with cultivars as treatments and four replicates per treatment was used. Three seeds of each cultivar were sown in loam soil in each of four labelled plastic pots; each pot measuring $15 \mathrm{~cm}$ in diameter and $15 \mathrm{~cm}$ in depth. The plants were thinned to one per pot at the three leaf stage. One potted plant of each cultivar was placed in each of four cages; giving a total of four plants per cultivar. Each cage was $40 \mathrm{~cm}$ long, $40 \mathrm{~cm}$ wide and $40 \mathrm{~cm}$ high; covered with a $32 \times 32$ mesh size lumite screen to prevent aphids from escaping from or invading the plants. The seedlings were watered ad lib.

\section{Aphid Infestation and Damage Assessment Methods}

Potted seedlings of each cultivar were artificially infested with cabbage aphid at the 4 to 5 leaf stage. One mature aphid was placed on each plant and left to produce nymphs for 24 hours and then removed. All except one of the nymphs were removed from each plant in order to start the experiment with the same number of aphids that were of the same age. The remaining nymph was left to develop to maturity and to breed. The abundance of aphids on each plant was assessed, using direct counts, once every 24 hours, during the first 7 days in order to detect when the initial nymph started to produce offspring. The nymphs laid were counted once a day.
Subsequent assessments were made once a week to determine the population dynamics of $B$. brassicae on each cultivar. Aphid counts on each cultivar were made on a $4 \mathrm{~cm}^{2}$ area demarcated at the centre of an infested leaf. Damage caused by cabbage aphids was assessed by estimating the intensity of honeydew damage and reduction of marketable leaves per plant. Data recorded included: total number of leaves, number of infested leaves; number of leaves covered with honeydew and number of marketable leaves per plant. The results were used to calculate percent damaged; percent marketable leaves and percent yield loss per plant.

\section{Plant Chemical Composition Assessment Methods}

Plant characteristics including total chlorophyll content, leaf thickness, water content and protein content were assessed and used to determine the influence of physical and chemical properties of the different leafy vegetables on the population dynamics of the cabbage aphid and the damage caused by the pest. The assessment of each characteristic was repeated three times.

\section{Leaf Thickness}

Five leaf discs cut from each cultivar were stuck together and a venire calliper was used to measure their collective thickness. The result was divided by the number of leaf discs to estimate the thickness of a single leaf. The assessment of leaf thickness was repeated three times.

\section{Leaf Water Content}

A cork borer of diameter $11.25 \mathrm{~mm}$ was used to cut 50 leaf discs from leaves of each of the cultivars. The fresh weight of the leaf discs was measured and then the discs were oven dried at $45^{\circ} \mathrm{C}$ for 16 hours. The dried discs were reweighed and the difference between the fresh weight and dry weight was used to estimate water content of the leaves. The assessment of water content was repeated three times.

\section{Total Chlorophyll Content}

Ten $11.25 \mathrm{~mm}$ diameter leaf discs were cut from plants of each cultivar using a cork borer and extracted in the dark For 10 hours, in $4 \mathrm{ml}$ of $0.1 \mathrm{~N} \mathrm{HCL}$ in methanol, at $21^{\circ} \mathrm{C}$. Absorbance of each extract was measured using a spectrophotometer at $650 \mu \mathrm{m}$ wavelength. Total chlorophyll was determined using the formula:

Total Chlorophyll $\left(\mathrm{mg} / \mathrm{cm}^{2}\right)=24.88 \times$ A650/sample area

Where $\mathrm{A}=$ Absorbance

\section{Protein Content}

Crude protein/nitrogen content was estimated using the steam distillation method [26]. A $25 \mathrm{ml}$ wet digest was pipetted into a distillation tube and $40 \mathrm{ml}$ of a $32 \% \mathrm{NaOH}$ solution was added automatically by the distillation unit. The distillation was carried out over a 3 minute period. The distillate was collected in a $1 \%$ boric acid solution which contained mixed indicators (methy red and bromocresol green). The solution was then back titrated using $0.115 \mathrm{~N} \mathrm{H}_{2} \mathrm{SO}_{4}$. Crude protein and nitrogen content were calculated using the formulae: 


$$
\begin{aligned}
& \% \mathrm{~N}=\frac{(\text { titre }- \text { blank }) \times \text { acid } \mathrm{N} \times \text { Dil. Factor } \times 0.014 \times 100}{\text { Weight of sample }} \\
& \% \text { Protein }=\% \mathrm{~N} \times 6.25 \\
& \text { Where } \mathrm{N}=\text { Nitrogen }
\end{aligned}
$$

\section{Data Analysis}

Data were analyzed using ANOVA and treatment means were separated at $P<0.05$ using Tukey test (Honest Significant Difference - HSD). Data of numbers of aphids were transformed to $\log _{10}(\mathrm{x}+1)$ while percentages were transformed to arcsines before analysis in order to normalize them.

\section{RESULTS}

The average number of cabbage aphids per leaf was significantly affected by the leafy vegetable cultivars and the period of infestation after the initial nymph commenced breeding (Fig. 1) (ANOVA, $\mathrm{P}<0.05$ ). The interaction between cultivar and period also had a significant effect. The greatest number (828.3 aphids per leaf) was on Chinese cabbage plants at 21 days, while the least $(0.0$ aphids/plant $)$ occurred on Chinese cabbage plants examined 42 days after the initial aphid started to produce offspring. The overall average number of aphids per plant was significantly greater on Chinese cabbage than on rape and Ethiopian mustard plants.
Overall aphid abundance increased significantly from 18.7 per plant on plants assessed after 7 days to a peak of 512 aphids per plant, 21 days after the initial aphid started to produce offspring; and then declined significantly to 163.6, 62.7 and 35.8 aphids per plant; 28,35 and 42 days after the aphids started producing offspring, respectively.

Fig. (2) shows that there was a very weak positive relationship $(\mathrm{r}=0.1140)$ between the average number of aphids per leaf and protein content in leaves of the leafy vegetables while Fig. (3) shows a very strong negative linear relationship $(r=-0.9799)$ between number of aphids and chlorophyll content per leaf. A negetive linear relationship was also found between average aphid abundance and water content (Fig. 4) $(r=-0.7921)$ and also between aphid abundance and leaf thickness (Fig. 5) $(r=-0.4882)$. Cultivars kale and Chinese cabbage which had significantly lower chlorophyll and water content per leaf had significantly greater abundance of aphids than rape and Ethiopian mustard, which had higher chlorophyll and water content. Chlorophyll is important for the production of carbohydrates in the leaf during photosynthesis. Chinese cabbage which had the thinnest leaves had the greatest abundance of aphids while Ethiopian mustard and kale, which had the thickest leaves, had the lowest number of aphids per leaf.

The results in Fig. (6) show that the average number of leaves covered with honeydew varied significantly with

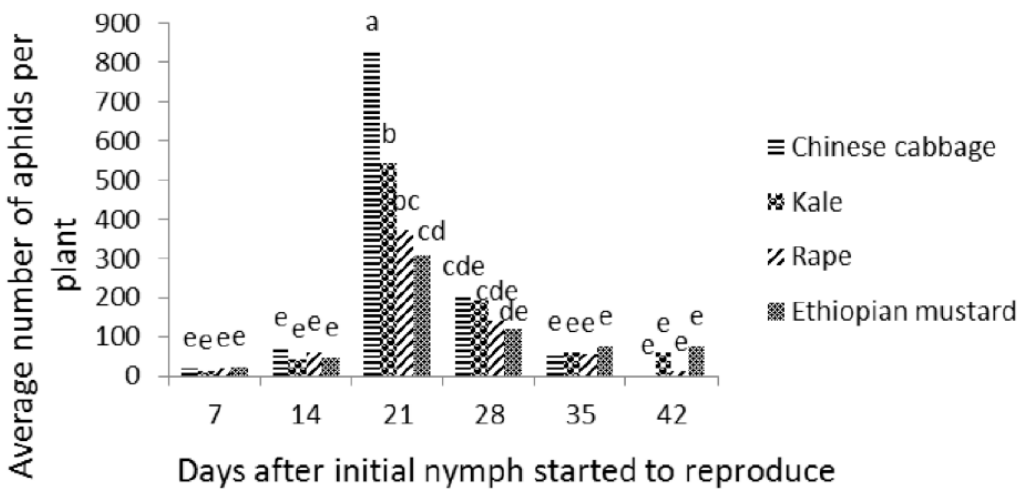

Fig. (1). Population dynamics of cabbage aphid on four brassica leafy vegetable over a six weeks period $(\mathrm{HSD}=38.04$ at $\alpha=0.05)$.

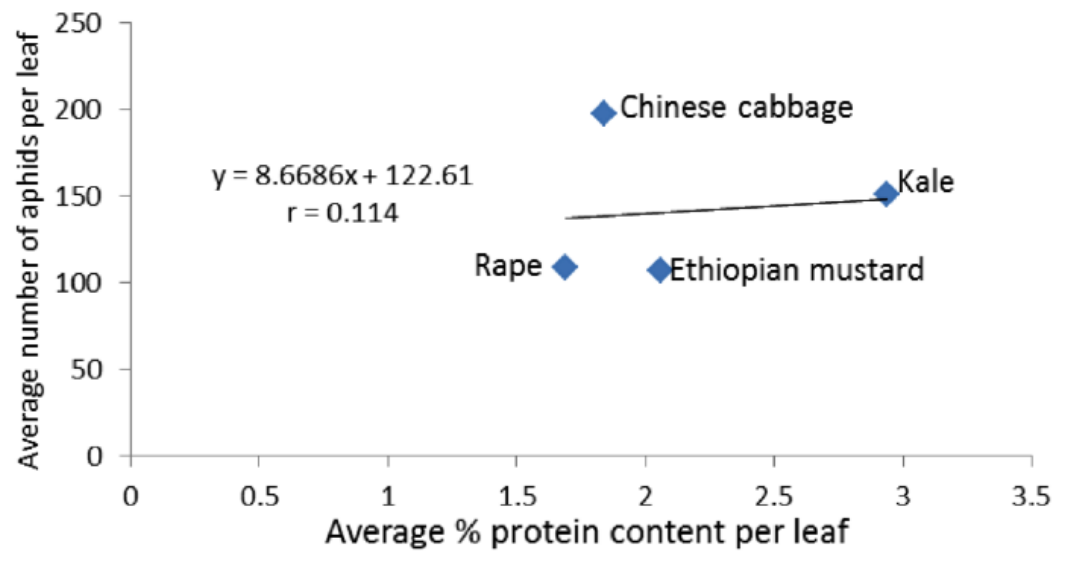

Fig. (2). Relationship between \% protein and the average number of aphids per leaf. 


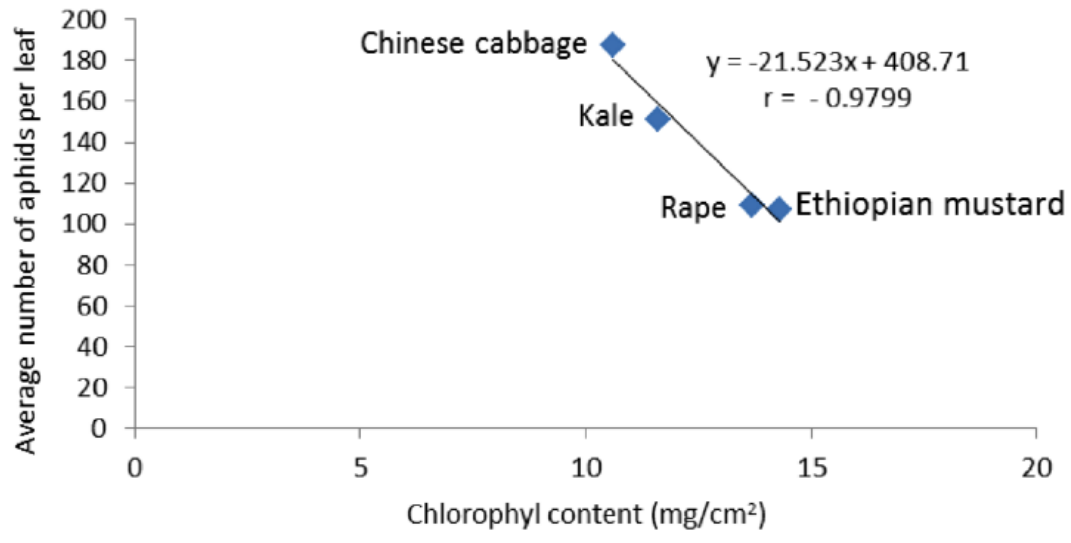

Fig. (3). Relationship between chlorophyll content and number of aphids per leaf.

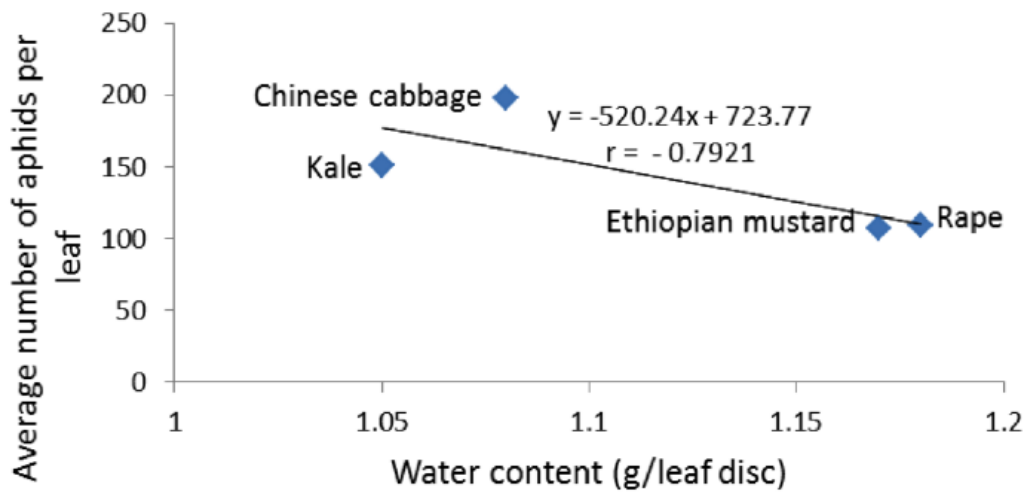

Fig. (4). Relationship between water content and average number of aphids per leaf.

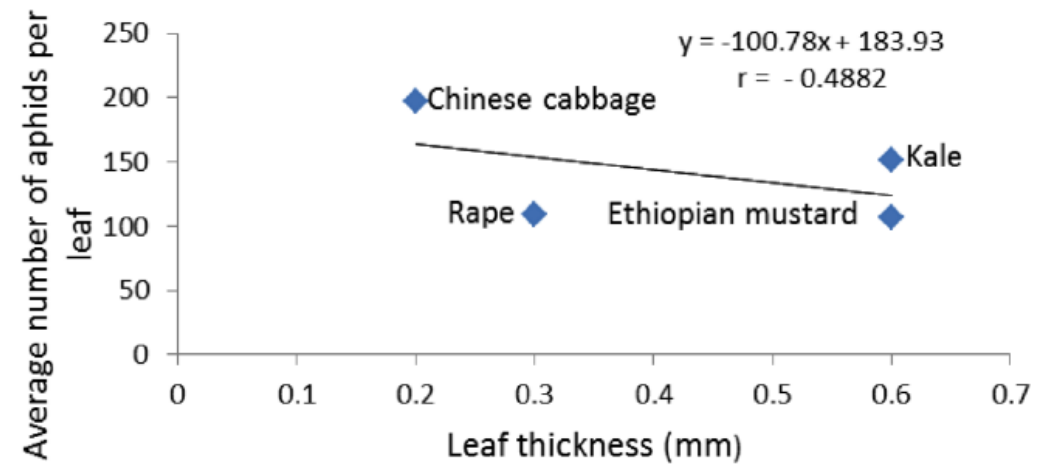

Fig. (5). Relationship between leaf thickness and average number of aphids per leaf.

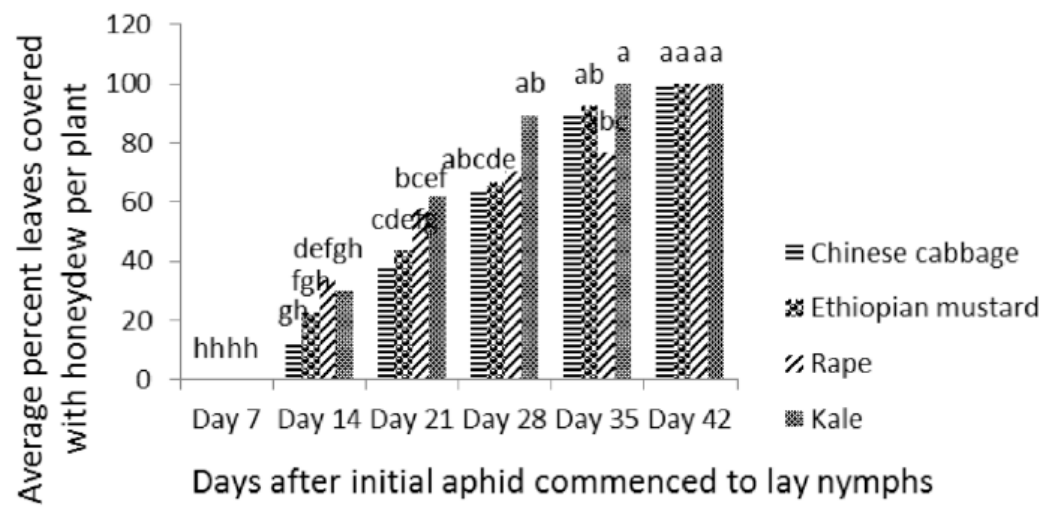

Fig. (6). Average percent leaves covered with honeydew per plant on different brassica leafy vegetable over a six week period $(\mathrm{HSD}=7.316$ at $\alpha=0.05$ ). 
cultivar as well as the period after initial aphid commenced breeding. The interactions between intensity of honeydew damage and period of aphid infestation show that the greatest percentage of leaves with honeydew was on kale plants assessed at 35 days and all cultivars assessed 42 days after aphids started to lay nymphs. None of the cultivars had detectable honeydew damage when assessed 7 days after the initial aphids started to lay nymphs. Overall percentage leaves covered with honeydew increased significantly from 0.0 at 7 days to $100 \%, 42$ days after the aphids started to lay nymphs. The overall percent leaves with honeydew was greatest $(82.5 \%)$ on kale and smallest $(50.7 \%)$ on Chinese cabbage plants.

Fig. (7) shows that there was a strong positive relationship $(r=0.9389)$ between protein content and the proportion of leaves covered with honeydew per plant; since Chinese cabbage and rape, which had the lowest protein content per leaf, had the smallest proportion of leaves covered with honeydew, while kale, with the highest percentage protein content had the largest proportion of leaves covered with honeydew. The relationship between the level of honeydew damage and water content (Fig. 8) was negative ( $\mathrm{r}=-0.6027)$. A positive relationship $(\mathrm{r}=0.6084)$ was found between the level of honeydew damage per plant and leaf thickness (Fig. 9). However, the relation between the level of honeydew damage and chlorophyll content (Fig. 10) was negative $(\mathrm{r}=-0.2285)$. Results in Fig. (11) show that the average percentage marketable leaves per plant was significantly (Tukey, $\mathrm{P}<0.05$ ) affected by the brassica leafy vegetable cultivar as well as assessment date. The interaction between cultivar and assessment date shows that the greatest percentage marketable leaves was on all the leafy vegetables when plants were assessed at 7 days and on Chinese cabbage and rape plants assessed at 14 days after the aphids started to lay nymphs. The smallest proportion $(0.0$ to $10.5 \%)$ was found on kale plants assessed at 28, 35 and at 42 days; and on rape, Ethiopian mustard and Chinese cabbage plants assessed at 35 and at 42 days after aphids started to lay nymphs. Overall average percentage marketable leaves per plant differed significantly (Tukey, $\mathrm{P}<0.05$ ) between cultivars. The percentage marketable leaves were greatest $(53.0 \%)$ on Chinese cabbage and rape plants and least $(39.4 \%)$ on kale. The overall percentage marketable leaves declined significantly (Tukey, $\mathrm{P}<0.05$ ) with time; from $100 \%$ at 7 days to $0.0 \%$ at
42 days after aphids started laying nymphs. Cultivar kale which had the greatest proportion of leaves covered with honeydew (Fig. 7) also had the the lowest percent marketable leaves per plant (Fig. 12). In contrast, Chinese cabbage and rape which had the lowest protein content and the lowest honeydew damage (Fig. 7) also had the highest percent maketable leaves per plant (Fig. 12).

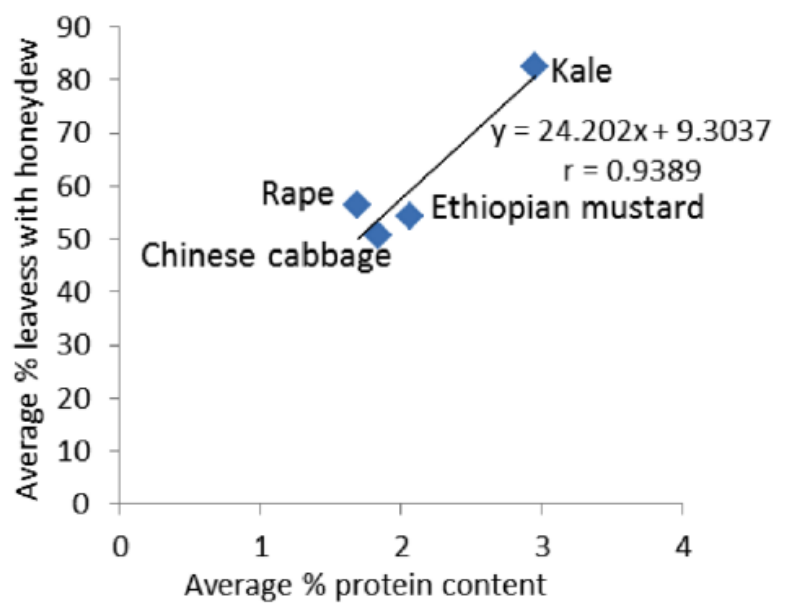

Fig. (7). Relationship between protein content and \% leaves covered with honeydew.

Although peak aphid abundance on all cultivar occurred at 21 days after the initial aphids commenced to lay nymphs (Fig. 1), the percent leaf yield loss at peak pest population was significantly greater on kale than on the other three cultivars (Fig. 12). The percent unsaleable leaves on kale plants at 21 days after aphids commenced laying was $3.4 \mathrm{x}$, $2.2 \mathrm{x}$ and $2.1 \mathrm{x}$ the proportion on rape, Chinese cabbage and Ethiopian mustard respectively. Leaf yield reduction on all cultivars, except Ethiopian mustard, were similar and above $50 \%$ per plant when assessed at 28 days after initial aphids started to lay nymphs (Fig. 12).

Fig. (13) shows that there is a negative straight line relationship $(\mathrm{r}=-0.9596)$ between the average percent marketable leaves per plant and the average percent protein content per leaf. Cultivars rape and Chinese cabbage which had significantly lower concentrations of protein had the

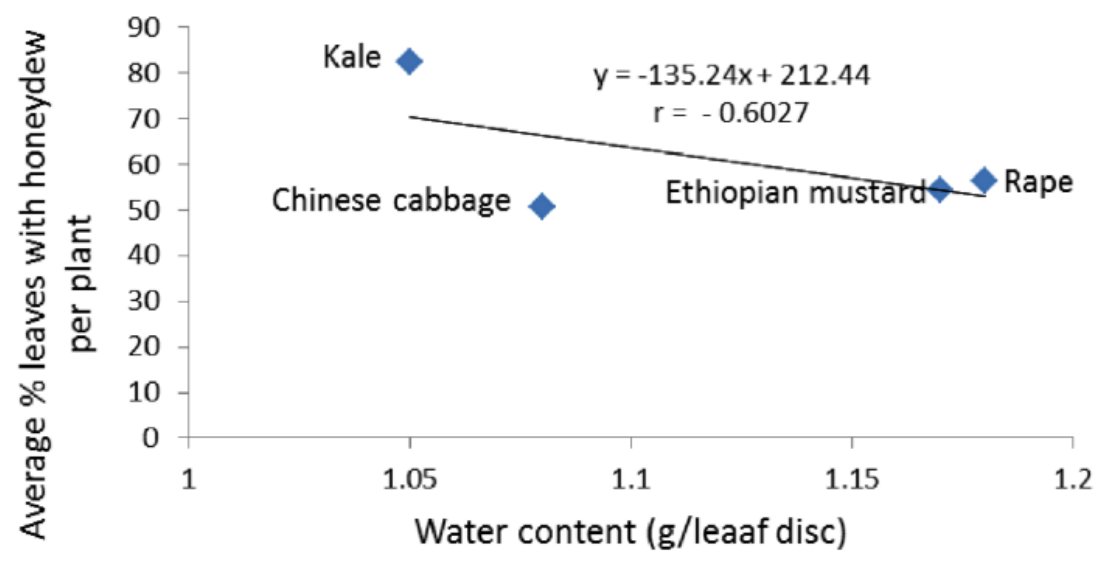

Fig. (8). Relationship between leaf water content and \% leaves with honeydew. 


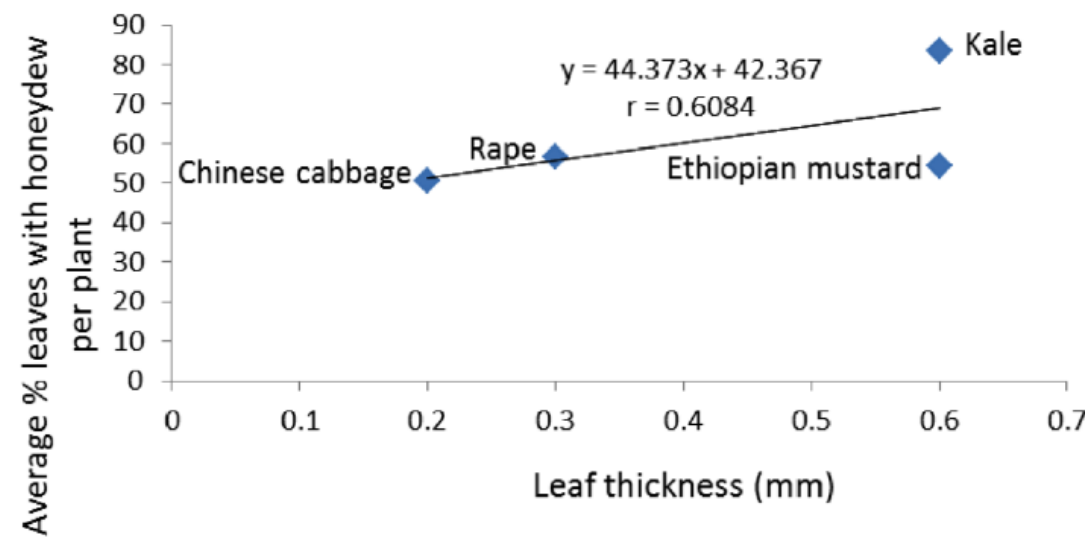

Fig. (9). Relationship between leaf thickness and \% leaves with honeydew.

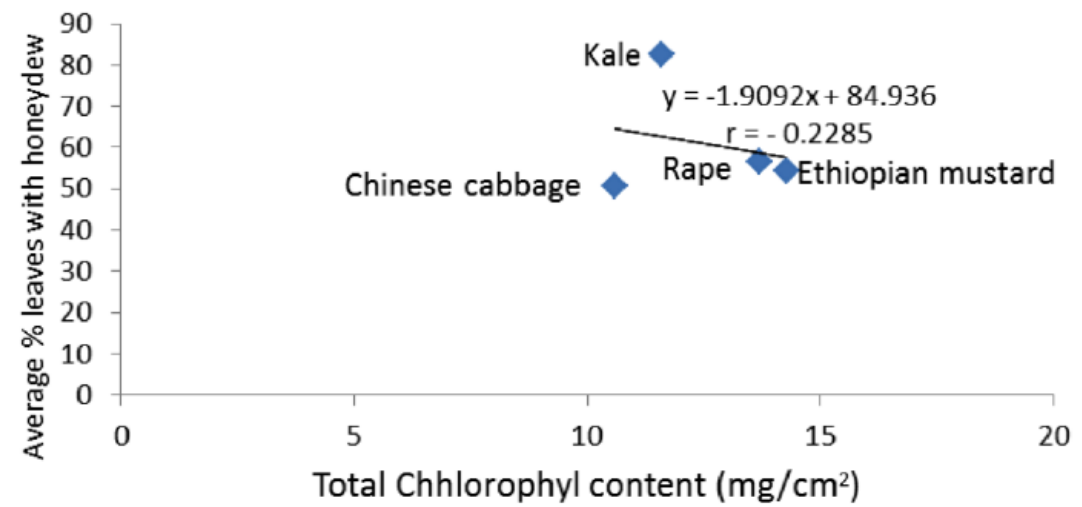

Fig. (10). Relationship between chlorophyll content and \% leaves with honeydew.

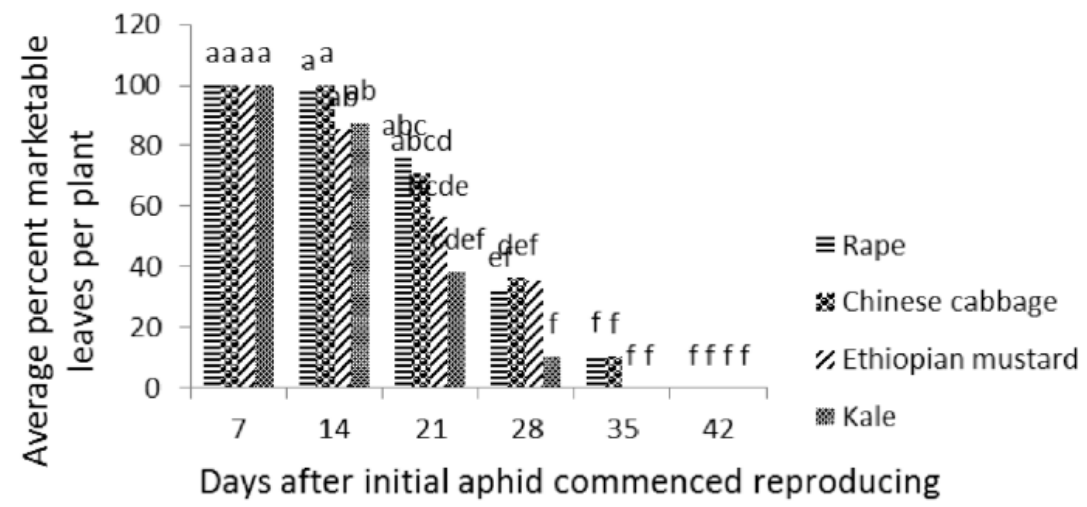

Fig. (11). Average percent marketable leaves per plant on infested plants (HSD $=7.62$ at $\alpha=0.05$ ).

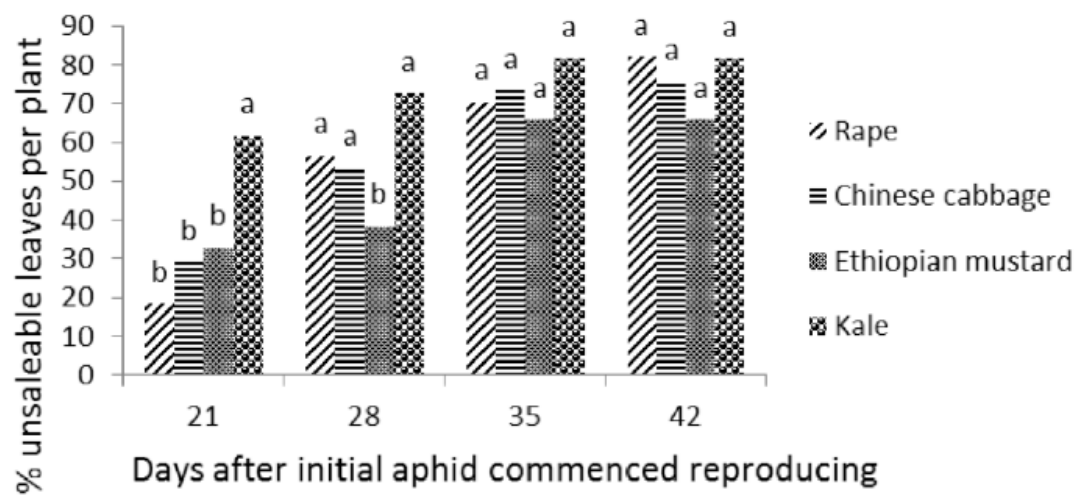

Fig. (12). Percent leaf yield loss per plant per cultivar after peak aphid population per cultivar $(\mathrm{HSD}=7.84$ at $\alpha=0.05)$. 


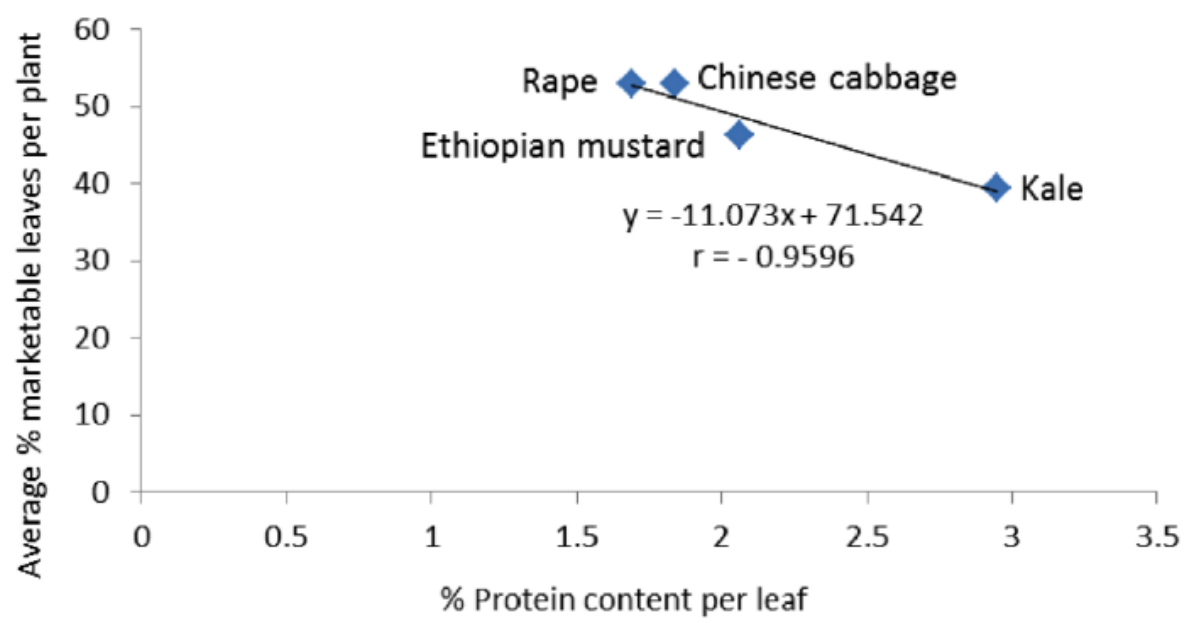

Fig. (13). Relationship between \% protein content per leaf and \% marketable leaves per plant.

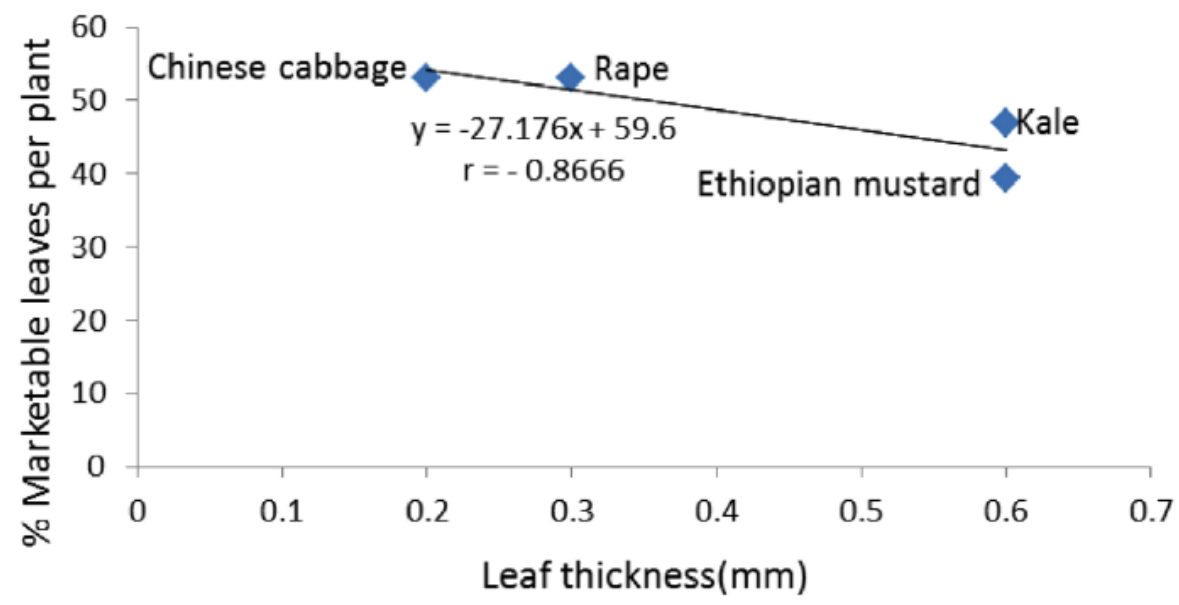

Fig. (14). Relationship between leaf thickness and \% marketable leaves per plant.

highest proportion of marketable leaves while kale which had the highest protein content had the lowest marketable leaves per plant.

Fig. (14) shows that there is a negative straight line relationship ( $r=-0.8666)$ between percent marketable leaves and leaf thickness. Cultivar kale, with the thickest leaves produced the lowest proportion, while Chinese cabbage which had the thinnest leaves produced the highest proportion of marketable leaves per plant.

\section{DISCUSSION}

The results in Fig. (1) show that the breeding behaviour of the cabbage aphid depends on the brassica leafy cultivar infested; thus indicating that crop resistance can play a role in the control of cabbage aphids. A similar breeding behaviour was reported by others on wild brassica species [18] and on cabbage varieties [21]; supporting the conclusion that resistant varieties should be a basis of integrated pest management of the cabbage aphid [16]. The negative linear relationships between total chlorophyll content and abundance of aphids between water content and average abundance of aphids per leaf (Figs. 3 and $\mathbf{4}$ respectively) show that high chlorophyll and water content result in low aphid abundance on leafy vegetables; the higher the chlorophyll content the lower the overall aphid abundance per leaf. Chlorophyll content could be used as an indicator of the level of photosynthesis that occurs in a leaf and in turn the level of carbohydrate produced per leaf. Aphids need carbohydrates for their energy requirements and protein for their growth and development. For optimal growth and development, insects require a balanced intake of carbohydrate and protein [27]. Results in Fig. (3) suggest that aphids fed on a high carbohydrate diet produce significantly fewer progeny than those fed on a low carbohydrate diet. This confirms conclusions by others [27] that carbohydrates are only important as a source of energy for aphids and not for growth, development and reproduction.

Aphids feed by piercing and sucking sap from infested leaves. An aphid that feeds on a leaf with high water content would ingest relatively lower concentrations of nutrients per unit feeding period than one feeding on a leaf with lower water content. The negative linear relationship between aphid abundance and water content (Fig. 4) shows that high water content results in low abundance of cabbage aphids on brassica leafy vegetables; Insects feeding on a host plant with high water content would ingest inadequate supply of major nutrient components; they would respond to the dietary deficiency by adjusting the total intake of food ingested; or by moving from one food to another [27]. The present 
study also suggests that the thicker the leaves of a cultivar the lower the abundance of aphids per leaf (Fig. 5). A cultivar with thicker leaves was probably more difficult for the aphid's stylets to penetrate, resulting in reduced intake of nutrients from the leaf compared to that with thinner leaves, suggesting that breeding for thick leaves can be used to produce cultivars that decrease cabbage aphid abundance. The factors found to influence abundance of cabbage aphid on different brassica cultivars in this study could explain the antibiosis and antixenosis resistance mechanisms reported by other researchers [18, 19, 21$]$.

The results in Fig. (6) suggest that honeydew damage by cabbage aphids depended on the cultivar infested. Aphids produce honeydew as they concentrate nutrients in the sap which they ingest during feeding. They feed on the undersides of leaves and secrete honeydew onto upper surfaces of lower leaves [28]; the honeydew makes the covered leaves sticky and is also ideal medium for growth of black sooty mould [29]. Leaves covered in honeydew tend to be sticky, of poor quality and unmarketable. The positive, linear relationship between the percent of leaves covered by honeydew and the protein content per leaf (Fig. 7) shows that the higher the protein content the greater the honeydew damage caused by the aphids. The proportion of leaves covered by honeydew reflects the intensity of damage caused by the aphids on the different brassica leafy vegetables evaluated. The results in Fig. (7) show that high protein content in brassica leafy vegetables causes increased feeding; resulting in a higher intensity of honeydew damage. Therefore, since cultivars with high protein content suffer greater honeydew damage than those with lower protein content, honeydew damage by cabbage aphids can be reduced by breeding for low protein content in brassica leafy vegetables.

\section{CONCLUSION}

Farmers grow leafy vegetables for own consumption and/or for the market. Therefore a cultivar that has the least abundance of the pest and produces the greatest quantities of marketable leaves per plant at harvesting time would be the best for cultivation in areas where cabbage aphid is a problem. This study has shown that such a cultivar should have: high chlorophyll and high water content in the leaves, to reduce aphid abundance; thin leaves and low protein content to reduce honeydew damage and produce high quantities of marketable leaves.

\section{CONFLICT OF INTEREST}

The authors confirm that this article content has no conflicts of interest.

\section{ACKNOWLEDGEMENTS}

The authors are gratiful to the Botswana College of Agriculture (BCA) for supporting the implementation of the study. We would also like to acknowledge the financial support from the USAID through the Sorghum, Millet and other Grain Legumes Collaborative Research Support Programme for providing the funds used to construct field cages used in this study.

\section{REFERENCES}

[1] Swaider JM, Gorge WW, Mc Cullum JP. Producing vegetable crops. USA; Interstate Publishers Inc 1992; p. 235.

[2] Bok I, Madisa M, Machacha D, Moamongwe M, More K. Manual for vegetable production in Botswana. Botswana; Gaborone; department of agricultural research, Ministry of Agriculture 2006; p. 52 .

[3] Agrinews. Botswana; Gaborone; Ministry of Agriculture 2009; p.12.

[4] Rohilla HR, Kumar PR. Managing the insect pests of mustard and rape seed. Indian Farm 1991; 40(12): 21-3.

[5] Bhatia R, Verma A. Seasonal incidence of major insect pests associated with winter crops of cabbage in Himachal Pradesh. Ann Agric Res 1994;15(2): 222-5.

[6] Dattu SK, Dattu BC. A preliminary survey of insect pests of rape seed mustard in Central Brahmaputra valley zone of Assam. Plant Health 1995; 1: 15-20.

[7] Munthali DC, Obopile M, Modise DM, et al. A guide to commercial production of selected vegetables in Botswana. Botswana; Gaborone; Printing and Publishing Company 2004: p. 91.

[8] Mc Cullum JP, Ware GM, Swiader JM. Producing vegetable crops. $3^{\text {rd }}$ ed. USA; Interstate Printers and Publishers Inc 1992: p. 607.

[9] Myburgh AC. Crop pests in Southern Africa, vol 3. South Africa; Petoria; Promrdia Publications 1993: p. 94.

[10] McKinley RG. Vegetable crop pests. $1^{\text {st }}$ ed. Hounmills, Basingstocke and London; MacMillan Academic and Professional Ltd. 1992: p. 321.

[11] Chivasa S, Ekpo EJA, Hicks RGT. New hosts of turnip mosaic virus in Zimbabwe. Plant Pathol 2002; 51(3): 386.

[12] Obopile M, Munthali DC, Matilo B. Farmers' knowledge, perceptions and management of vegetable pests and diseases in Botswana. Crop Protect 2008; 27: 1220-4.

[13] Nel A, Krause M, Khelawanlall N. A guide for the control of plant pests. RSA, Pretoria; National Department of Agriculture, Government Printer 2002; p. 231.

[14] O'Connor-Marer PJ. The safe and effective use of pesticides. USA; University of California state wide integrated pest management project. Agriculture and Natural Resources Publication 3324. 2000; p. 342.

[15] Ware GW, Whitacre DM. The pesticide book. USA; MeisterPro Information Resources 2004; p. 488.

[16] Russel GE. Plant breeding for pest and disease resistance. London, Boston; Butterworths 1978; p. 485.

[17] Sastrosiswojo S, Permadi A, Dibiantoro AL, Misra I. Resistance of crucifers to the diamond back moth Plutella xylostella. Bull Pernel Hortikut 1987; 15(1): 29-37.

[18] Ellis PR, Kift NB, Pink DAC, Jukes PL, Lynn J, Tatchell GM. Variation in resistance to cabbage aphid (Brevicoryne brassicae) between and within wild and cultivated brassica species. Gene Resour Plant Evol 2000; 47: 395-401.

[19] Kalule T, Wright DJ. Effect of cabbage cultivars with varying levels of resistance to aphids on performance of the parasitoid, Aphidius colemani (Hymenoptera: Braconidae). Bull Entomol Res 2002; 93 (1): 53-9.

[20] Pakhraj P, Ganduli RN, Ganduli J, Dubey VK. Pest succession in cabbage at Raipur, Chhattisgarh (India). J Appl Zoologic Res 2005; 16(1): 28-9.

[21] Munthali DC. Evaluation of cabbage varieties for resistance to the cabbage aphid. Afr Entomol 2009; 17 (1): 1-7.

[22] Singh R, Ellis PR. Sources, mechanisms and bases of resistance in Cruciferae to the cabbage aphid Brevicoryne brassicae (Homoptera: Aphididae), at Vancouver British Columbia. 1. Sampling methods and population trends. In: Breeding for resistance in insects and mites. Bull IOBC/WPRS 1993; 16(5): 21-35.

[23] Ellis PR, Pink DAC, Phelps K, Juke PL, Breeds SE, Pinnegar AE. Evaluation of cole collection of Brassica oleracea accessions for resistance to Brevicoryne brassicae, the cabbage aphid. Euphytica 1998; 103: 149-60

[24] Collier RH, Finch S. IPM Case Studies: Brassicas. In: van Emden HF, Harrington, Eds. Aphids as crop pests. CABI 2007; 549-72.

[25] van Emden HF. Integrated pest management and introduction to ipm case study (IPM). In: van Emden HF, Harrington, Eds. Aphids as crop pests. CABI $2007 ; 537-48$. 
[26] Cunniff P. Official methods of analysis of AOAC international. $16^{\text {th }}$ ed. Gaithersburg, Maryland. AOAC Int 1995; 4: 19-22.

[27] Chapman RF. The Insect: structure and function. $4^{\text {th }}$ ed. Tucson, Arisona and Cambridge. Cambridge University pres 1997: 770.

[28] Blackman RL, Eastop VF. Aphids on the World's Crops: an identification and information guide. $2^{\text {nd }}$ ed. Chichester, New York,
Weinheim, Brisbane, Singapore, Toronto. John Wiley and Sons Ltd. 2000: 466.

[29] Parker BL, Talekar NS, Skinner M. Field guide: Insect pests of selected vegetables in tropical and sub-tropical Asia. Shanhua, Taiwan. Asia Veg Res Develop Cent 1995: 164.

Received: February 02, 2014

Revised: April 04, 2014

Accepted: April 08, 2014

(C) Munthali and Tshegofatso; Licensee Bentham Open.

This is an open access article licensed under the terms of the Creative Commons Attribution Non-Commercial License (http://creativecommons.org/licenses/by-nc/3.0/) which permits unrestricted, non-commercial use, distribution and reproduction in any medium, provided the work is properly cited. 